\title{
Serological survey for equine viral arteritis in several municipalities in the Orinoquia region of Colombia
}

\author{
Monitoreo serológico de arteritis viral equina en municipios de la \\ Orinoquia, Colombia
}

\author{
Agustín Góngora O, ${ }^{1 *}$ Ph.D, María Barrandeguy, ${ }^{2}$ Ph.D, Karl Ciuoderis A, ${ }^{3}$ MVZ.
}

\begin{abstract}
${ }^{1}$ Universidad de los Llanos, School of Animal Sciences, Reproduction and Animal Genetics Investigation Group, Villavicencio, Km. 12 Vía Puerto López, Meta, Colombia. ${ }^{2}$ Universidad del Salvador, Infectious Diseases Department, Veterinary Career and Equine Virus Laboratory, Institute of Virology CICVyA INTA. Av. Callao y Córdoba (C1023AAB) Ciudad Autónoma de Buenos Aires, Argentina. ${ }^{3}$ WisconsinMadison University, Department of Pathobiological Sciences, Veterinary Medicine School, Madison, WI 53706, USA. *Correspondence: agongora@unillanos.edu.co
\end{abstract}

Received: October 2013; Accepted: April 2014.

\begin{abstract}
Objective. The goal of this study was to determine the current status of the Equine Arteritis virus (EAV) in horse populations in the Orinoquia region of Colombia. Materials and methods. A transversal study was conducted by serological survey of equine $(n=100)$ from 11 municipalities of the Colombian Orinoquia region. Serum samples were tested by virus seroneutralization assay according to the guidelines provided by the World Organization for Animal Health. Results. After testing was carried out no positives samples to EAV were found in the population analyzed. Conclusions. Although the sample size of the population screened in this study does not represent the total equine population size for the region or the country, data obtained has shown the absence of EAV infection in these animals. However, a wider study area including other regions of the country, with a feasible statistical design, would determine if this infection continues to be an exotic disease for Colombia.
\end{abstract}

Key words: Antibodies, epidemiology, prevalence, virus (Source: DeCS).

\section{RESUMEN}

Objetivo. Determinar la condición sanitaria relativa a la infección con el virus de la arteritis (VAE) en equinos de la Orinoquia, Colombia. Materiales y métodos. Se realizó un muestreo serológico transversal en equinos ( $\mathrm{n}: 100)$ provenientes de 11 municipios, de la región de la Orinoquia, Colombia. Los sueros fueron analizados por la técnica de seroneutralización viral de acuerdo con lo recomendado por la Organización Internacional de Sanidad Animal (OIE). Resultados. No se identificaron reactores al VAE en la población analizada. Conclusiones. Si bien la población estudiada no representa el total de los equinos de la región, ni del país, los datos obtenidos evidencian la ausencia de infección por VAE en estos animales. Un estudio ampliado, estadísticamente diseñado, incluyendo otras regiones del país permitiría determinar fehacientemente si esta infección continua siendo exótica para Colombia.

Palabras clave: Anticuerpos, epidemiología, prevalencia, virus (Fuente: DeCS). 


\section{INTRODUCTION}

The arteritis virus is a widely diffused infectious disease around the world that, in addition to affecting equines, affects donkeys, mules and zebras. It is produced by a RNA virus of the Arteriviridae family of the Nidoviral order that includes three other virus; the porcine reproductive and respiratory syndrome virus (PRRVS), the simian hemorrhagic fever virus (SHFV) and the murine lactate dehydrogenase elevating virus (LDV) (1).

The name of the disease is associated with inflammatory lesions in the veins, especially the arterioles (2), and has been reported in North And South America, Europe, Asia, Australia and Africa, with the exception of Iceland and Japan (3), and more recently in New Zealand (4). Seroprevalence varies considerably from country to country and among breeds (5).

The infection can be asymptomatic (in the majority of cases) or present several symptoms such as fever, loss of appetite, nasal secretion, and conjunctivitis, which are similar to those caused by other respiratory virus (influenza or equine herpes virus 1 and 4). Some other clinical signs can be present such as pruritus, edema of the scrotum or mammary glands, and abortions (6). After an acute infection in sexually mature males, between $30-50 \%$ of the animals can maintain a persistent infection and the virus is expelled with semen (7). These animals become the principal disseminators of the virus, whether in the short or medium term or for the rest of their lives, becoming the greatest threat to free populations (5). The World Organization for Animal Health (OIE) included it in the unique list of diseases of compulsory notification for land and marine animals since its presence restricts commerce between countries (8).

Colombia is not presently aware of the presence of this disease; however, identification of herpes virus 1 and 4 reactors (9) that presents clinical symptoms similar to EAV, importing animals from countries where the disease has been reported in addition to the possible illegal entry of persistently infected animals over the extensive land borders increases the probability that this infection is present in the country and is not being diagnosed by the health authorities and veterinarians.

In the Orinoquia region equines are a valuable resource for managing extensive livestock and more recently due to the popularity of sporting

\section{INTRODUCCIÓN}

La arteritis viral es una enfermedad infecciosa de amplia difusión mundial que además de los equinos, afecta asnos, mulas y cebras. Es producida por un virus RNA de la familia Arteriviridae del orden Nidovirales que incluye otros tres virus, el virus del síndrome respiratorio reproductivo porcino (PRRVS), el virus de la fiebre hemorrágica del simio (SHFV) y el virus del aumento de la lactato deshidrogenasa murina (LDV) (1)

El nombre de la enfermedad se asocia con las lesiones inflamatorias que ocasiona a nivel de los vasos sanguíneos, especialmente las arteriolas (2), ha sido reportada en Norte y Suramérica, Europa, Asia, Australia y Africa con excepción de Islandia y Japón (3) y más recientemente Nueva Zelanda (4). La seroprevalencia varia considerablemente entre países y entre razas (5).

La infección puede ser asintomática (en la mayoría de los casos) o presentar diversos signos clínicos, como fiebre, inapetencia, secreción nasal, conjuntivitis que son similares a los ocasionados por otros virus respiratorios (influenza o herpesvirus equino 1 y 4). También pueden presentarse otros signos clínicos como prurito, edema de miembros, escroto o glándula mamaria, y abortos (6). Después de una infección aguda en machos sexualmente maduros, entre el $30-50 \%$ de los animales pueden permanecer infectados persistentemente y el virus es eliminado por semen (7). Estos animales, se convierten en los principales diseminadores del virus ya sea por un período corto, de mediano plazo o por el resto de la vida, constituyéndose en la mayor amenaza para las poblaciones libres (5). La Organización Mundial de Sanidad Animal (OIE), la incluyó en la lista única de enfermedades de notificación obligatoria para animales terrestres y acuáticos debido a que constituye una limitante para el comercio entre países (8).

En la actualidad, en Colombia no se tiene conocimiento de la presencia de esta enfermedad; sin embargo, la identificación de reactores a los herpes virus 1 y 4 (9) que presentan cuadros clínicos similares a la EAV, la importación de animales de países en donde la enfermedad ha sido reportada, más el posible ingreso de animales infectados persistentemente de manera ilegal a través de la extensa frontera terrestre, aumentan la probabilidad de que esta infección se encuentre en el país y no esté siendo diagnosticada por las autoridades sanitarias y el cuerpo médico veterinario.

Para la región de la Orinoquia los equinos representan un valioso recurso para el manejo de la ganadería extensiva y más recientemente, por 
and recreational activities which have caused a notable increase in the equine population. The objective of this study was to determine the presence of EAV serological reactors in the equine population of this region that constitutes $38 \%$ of the Colombian territory.

\section{MATERIALS AND METHODS}

Animals. A transversal sampling was done with a selected group of 100 equines from the municipalities of Villavicencio $(n=19)$, San Martin $(n=10)$, Restrepo $(n=10)$, Puerto López $(n=10)$, Puerto Lleras $(n=10)$, Yopal $(n=10)$, Arauquita $(n=7)$ Arauca $(n=3)$, Puerto Gaitán $(n=10)$, San José del Guaviare $(n=10)$ and Guamal $(n=1)$, (Figure 1$)$. The animals came from 22 farms and the following breeds: Silla Argentina $10(10 \%)$, Quarter Horse 12 (12\%), criollo $74(74 \%)$, mule $3(3 \%)$ and Percheron $1(1 \%)$. Distribution by sex of the adult animals was 47 males and 53 females. The municipalities that the animals came from are found in the 4 departments of the subregion known as Los Llanos Orientales.

$5 \mathrm{ml}$ of blood from each animal was taken from the jugular vein in ad-hoc vacuum tubes (vacutainer ${ }^{\circledR}$ ), after clot retraction it was centrifuged at $3500 \mathrm{rpm}$ for 5 minutes, the resulting serum was fractioned by duplication in aliquots of $1 \mathrm{ml}$ into plastic Ependorff ${ }^{\circledR}$ tubes and maintained at $-70^{\circ} \mathrm{C}$ until processed.

Viral neutralization test. The serum was processed at the Institute of Virology - Veterinary and Agronomic Investigation Center (INTAArgentina) using the microseroneutralization technique for EAV virus (Arvac vaccination strain). Equine serums of international reference were used as positive and negative controls, provided by Dr. P. Timoney from The Gluck Equine Research Center (Kentucky University, USA) following the procedure described in the OIE manual (10). Briefly, the equine serums were inactivated at $56^{\circ} \mathrm{C}$ for 30 minutes and were then diluted in a cellular culture (MEM E) in base two dilutions from $1: 2$ to $1: 256$ and incubated for 1 hour at $37^{\circ} \mathrm{C}$ with a virus suspension that contained 100 DICT $50 \% / \mathrm{ml}$. After incubation a cellular suspension was added that contains 10000 cells (RK13) per $\mathrm{ml}$. All this was done in microplates for cellular cultures of 98 plates. Controls were carried out to confirm the title of the virus and a strong positive control, a weak one, and a negative serum were incorporated into the study. The reaction was read in an inverted microscope at 100 magnification where the cytopathic effect produced by the non- el auge en las actividades deportivas y recreativas, lo que ha incrementado notablemente la población equina. El objetivo de este estudio fue determinar la presencia de reactores serológicos a la EAV en la población equina de esta región que constituye el $38 \%$ del territorio colombiano.

\section{MATERIALES Y MÉTODOS}

Animales. Se realizó un muestreo transversal con selección de individuos por conveniencia en 100 equinos, provenientes de los municipios de Villavicencio $(n=19)$, San Martin $(n=10)$, Restrepo $(n=10)$, Puerto López $(n=10)$, Puerto Lleras $(n=10)$, Yopal $(n=10)$, Arauquita $(n=7)$ Arauca $(n=3)$, Puerto Gaitán $(n=10)$, San José del Guaviare $(n=10)$ y Guamal $(n=1)$, (Figura 1$)$. Los animales provenían de 22 fincas y pertenecían a las razas Silla Argentina 10 (10\%), Cuarto de Milla 12 (12\%), criollo 74 (74\%), mular 3 (3\%) y Percherón 1 (1\%). La distribución por sexo en animales adultos fue 47 machos y 53 hembras. Todos los municipios de procedencia de los animales se encontraban ubicados en 4 departamentos en la subregión conocida como los Llanos orientales.

De cada animal se obtuvieron $5 \mathrm{ml}$ de sangre de la vena yugular en tubos ad-hoc con vacío (vacutainer ${ }^{\circledR}$ ), luego de la retracción del coagulo se centrifugaron a $3500 \mathrm{rpm}$ por 5 minutos, el suero obtenido fue fraccionado por duplicado en alícuotas de $1 \mathrm{ml}$ en tubos plásticos tipo Ependorff ${ }^{\circledR}$ y mantenidos $\mathrm{a}-70^{\circ} \mathrm{C}$ hasta su procesamiento.

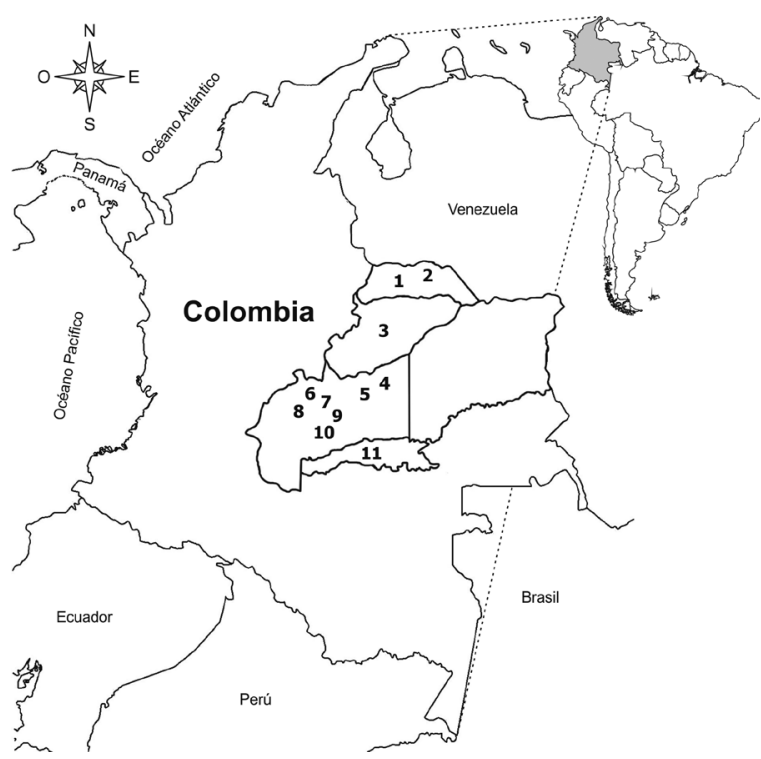

Figure 1. EAV sampling areas in Orinoquia. 1: Arauca, 2: Arauquita, 3: Yopal, 4: Puerto Gaitán, 5: Puerto López, 6: Restrepo, 7: Villavicencio, 8: San Martín, 9: Guamal, 10: Puerto Lleras, 11: San José del Guaviare. 
neutralized virus was determined. The antibody title of a determined serum was expressed as the inverse of the maximum dilution of serum that totally "neutralized" the 100 DICT 50\%/ $\mathrm{ml}$ of viral equine Arteritis virus.

\section{RESULTS}

All of the analyzed samples (100/100) were negative for seroneutralization for detecting EAV antibodies.

\section{DISCUSSION}

The results obtained infer that EAV is not present in the equine population in the region, this being the first study done in Colombia that tries to indirectly determine the presence of EAV. In spite of the number of breeds included in the sampling and the varied origin of the animals, the absence of reactors indicates that these animals have not been in contact with the virus. Similarly, due to the small amount of animals sampled, the need for a new study in a statistically determined population that allows a greater certainty of the EAV health situation in the country is considered.

In Colombia, importing equines and semen has been continually increasing in recent years. In 20081.212 animals and 400 semen doses were imported, and in 20091.436 animals and 1.548 semen doses were imported, in 20101,004 animals were imported. This tendency was maintained through 2011-2013, with the entry of 1.347 animals, the majority of them for competitions, recreation or breeding (Table 1 ), (11). The

Table 1. Equines imported into Colombia by country of origin and number of animals during the period 2011-2013 (ICA, 2013). (11)

\begin{tabular}{lcl}
\hline $\begin{array}{c}\text { Country } \\
\text { of origin }\end{array}$ & $\begin{array}{c}\text { Number of } \\
\text { animals }\end{array}$ & \multicolumn{1}{c}{ Destination } \\
\hline $\begin{array}{l}\text { United } \\
\text { States* }\end{array}$ & 547 & Breeding \\
Argentina* & 436 & Breeding, work horses \\
Spain* & 97 & $\begin{array}{l}\text { Reproducción, Competition and sport } \\
\text { Belgium* }\end{array}$ \\
Holland* & 396 & Breeding \\
Portugal & 37 & Breeding \\
France* & 18 & Breeding, Performance \\
Chile & 21 & Competition and sport \\
Puerto Rico & 15 & Competition and sport \\
Venezuela & 12 & Competition and sport \\
Mexico & 7 & Competition \\
Ecuador & 17 & Breeding \\
Peru & 3 & Breeding \\
Aruba & 3 & Competition and sport \\
Costa Rica & 1 & Competition and sport \\
Uruguay & 1 & Breeding \\
\hline Total & 1360 & \\
\hline *Countries where EAV outbreaks have been reported
\end{tabular}

Prueba de neutralización viral. Los sueros se procesaron en el Instituto de Virología-Centro de Investigaciones en Ciencias Veterinarias y Agronómicas (INTA-Argentina), mediante la técnica de microseroneutralización frente a virus de EAV (cepa vacunal-Arvac). Se utilizaron como control positivo y negativos sueros equinos de referencia internacional provistos por el Dr. P. Timoney, del Gluck Equine Research Center (Universidad de Kentucky-USA), siguiendo el procedimiento descrito en el manual de la OIE (10). Brevemente, los sueros equinos fueron inactivados a $56^{\circ} \mathrm{C}$ durante 30 minutos y posteriormente diluidos en medio de cultivo celular (MEM E) en diluciones de base dos, desde 1:2 hasta 1:256 e incubados durante 1 hora a $37^{\circ} \mathrm{C}$ con una suspensión de virus que contenia 100 DICT $50 \% / \mathrm{ml}$. Luego de la incubación se agrega una suspensión celular que contiene 10.000 células (RK13) por ml. Todo esto se realiza en microplacas para cultivos celulares de 96 pocillos. Se realizan controles para confirmar el título del virus y se incorporan al ensayo, un control positivo fuerte, uno débil y un suero negativo. La reacción se leyó en microscopio invertido a 100 aumentos donde se determinó el efecto citopático producido por el virus no neutralizado. El título de anticuerpos de un determinado suero se expresó como la inversa de la máxima dilución de suero que "neutralizó" totalmente las 100 DICT $50 \% / \mathrm{ml}$ de virus de Arteritis viral equina.

\section{RESULTADOS}

El total de muestras analizadas (100/100) resultaron negativas por seroneutralización para la detección de anticuerpos contra el EAV.

\section{DISCUSIóN}

Los resultados obtenidos permiten inferir que el EAV no ha circulado en la población equina de la región, siendo este el primer estudio realizado en Colombia que intenta determinar de manera indirecta la presencia del EAV. A pesar del número de razas incluidas en el muestreo y la variada procedencia de los animales, la ausencia de reactores indica que estos animales no han estado en contacto con el virus. Asimismo, debido al reducido número de animales muestreados, se plantea la necesidad de un nuevo estudio en una población estadísticamente determinada que permita conocer con mayor certeza la situación sanitaria relativa a EAV en el país.

En Colombia, la importación de equinos y semen en los últimos años ha venido en constante aumento. En 2008 se importaron 1.212 animales y 400 dosis de semen, en 2009 fueron 1.436 animales y 1.548 dosis de semen, en el 2010 se importaron 1.004 animales. Esta tendencia se mantuvo para 
introduction of imported animals occurred by air at the El Dorado airports (Bogota) and José María Córdoba (Rionegro-Antioquia) and their final destination were the departments of Cundinamarca and Antioquia, where the greatest population of equines in the country is, far from where this study was performed.

In Colombia a large number of imported animals or frozen semen comes from countries that have reported EAV outbreaks, such as Argentina (12), the European Union (13), France, (14), Spain (15), Holland (16) and Belgium (17), which carries the potential risk of introducing persistently infected animals or infected frozen semen. An example that illustrates this situation is the entry of the virus into Argentina through frozen semen from Holland on more than one occasion $(12,18)$. In another example the first outbreak occurred in the United Kingdom was due to importing a horse from Eastern Europe that had the virus (19). An EAV outbreak in the Normandy region in France (20) had a similar origin. In Italy an outbreak was reported associated with a horse imported from Germany that was seronegative, but after remaining for a time on the farm it presented seroconversion and later the virus was isolated from the semen (21). Lastly, the most recent outbreak in the United Kingdom occurred due to the entry of an animal infected in a breeding center (22).

Another aspect that merits analysis is the increase in the national commercialization of semen. Although the requirements to register technical units related to verifying the quality of seminal material and auditing semen and embryo production centers were established by means of ICA's Resolution 01426 from 2002 (23), said regulation is not complied with since there are few artificial insemination (AI) and embryo transfer centers. Resolution 02820 of 2001 regulates the technical control of producing, importing, and commercializing semen and embryos (24). The above shows that a large part of obtaining and commercializing semen is done among farms, without the supervision of health authorities.

This fact suggests the need to constantly monitoring donor animals, which should be done with a permanent diagnostic support, whether through the official sanitary authorities or universities. In this respect, certain countries require semen donor animals to be seronegative or viral isolation tests performed on the semen for those that are seropositive (3), requirements that are not met by the breeders in the country. el 2011-2013, con un ingreso de 1.347 animales, la mayoría con destino a la competencia, la recreación o la reproducción (Tabla 1), (11). El ingreso de los animales importados ocurrió vía aérea por los aeropuertos El dorado (Bogotá) y José María Córdoba (Rionegro-Antioquia) y su destino final fueron los departamentos de Cundinamarca y Antioquia, en donde se concentra la mayor población equina del país, lugares distantes al sitio en donde se realizó este estudio.

En Colombia, un gran número de animales importados y/o semen congelado provienen de países en donde se han reportado brotes de EAV, como Argentina (12), EU (13), Francia (14), España (15), Holanda (16) y Bélgica (17), lo cual conlleva un riesgo potencial de introducir animales persistentemente infectados, o semen congelado infectado. Un ejemplo que ilustra esta situación, es el ingreso del virus a Argentina a través de semen congelado proveniente de Holanda en más de una oportunidad $(12,18)$. Otro ejemplo, el primer brote ocurrido en el Reino Unido por la importación de un caballo portador del virus desde Europa del Este (19). Similar origen tuvo un brote de EAV en la región de Normandía en Francia (20). En Italia se reportó un brote el cual se asoció con un caballo importado desde Alemania que había sido seronegativo, pero que luego de permanecer algún tiempo en la finca presentó seroconversión y posteriormente se aisló el virus del semen (21). Por último, el brote más recientemente en el Reino Unido ocurrió por el ingreso de un animal infectado a un criadero (22).

Otro aspecto que amerita el análisis, es el aumento de la comercialización del semen a nivel nacional. Si bien mediante la resolución 01426 de 2002 del ICA (23), se establecen los requisitos para el registro de las Unidades técnicas relacionadas con la verificación de la calidad del material seminal y la auditoria de los centros de producción de semen y embriones, dicha reglamentación no se cumple puesto que son pocas las centrales de inseminación artificial (IA) y transferencia de embriones. Igualmente la resolución 02820 de 2001 reglamenta el control técnico de la producción, importación y comercialización de semen y embriones (24). Lo anterior evidencia que gran parte de la obtención y comercialización del semen se realiza entre fincas, sin la supervisión de las autoridades sanitarias.

Este hecho permite sugerir un monitoreo constante de los animales donantes, que debería estar acompañado por un permanente apoyo diagnóstico, ya sea por parte de las autoridades sanitarias oficiales o las Universidades. A este respecto, ciertos países exigen que los animales donantes de semen sean seronegativos o se realicen pruebas de aislamiento viral en el semen de los que resultan 
Within the breeds included in this study, samples come from the municipality of San Martín, belonging to the Silla Argentina breed. In 20091000 horses from this country were imported, however in 2010 ICA temporarily suspended importations for 6 months due to a state of alert concerning EAV outbreaks (25). In spite of this precedent, there was no evidence of the presence of virus reactors in these imported animals. The absence of reactors in this group also shows that these animals had not been vaccinated.

Another area of concern was along the extensive border with Venezuela, close to the Arauca and Arauquita municipalities where $10 \%$ of the samples were from; however, the results were also negative. The need for new studies in other municipalities along the border is seen, since the presence of the virus in the neighboring country is not clear. A preliminary study of 1008 samples in 5 states in the center of the country showed a prevalence of $2.48 \%$ (26).

The equine population in Colombia is estimated to be at about 1.533 .432 animals (27); therefore the presence of this disease would be devastating for the national industry. In countries that have suffered the effects of this disease the direct economic loss has been associated with abortions, death of young animals, loss in the commercial value of the breeders, reduction in the demand for semen, vaccination costs, cancelation of equine events and international markets $(3,28)$. There is a need for active surveillance regarding the presence of this disease in the country.

There is no evidence of EAV infection in the analyzed population, which is to say that these animals have not had contact with the EAV virus. These results are very encouraging; however new studies are required in a wider population that can be extended to other regions of the country to confirm the state of this exotic disease in Colombia.

Conflict of interests. The authors declare that there is no conflict of interests.

\section{Acknowledgement}

Dra. Piedad Cristina Rivas from the Universidad de la Salle for supporting in obtaining the samples. María Roció Parra Molina for managing and preserving the samples. seropositivos (3) exigencias que no se cumplen con los reproductores en el país.

Dentro de las razas incluidas en el estudio, las muestras que provenían del municipio de San Martín pertenecían a la raza Silla Argentina, con relación a esto, en el año 2009 se importaron 1.000 equinos de este país, no obstante, en el 2010 las importaciones fueron suspendidas temporalmente por el ICA durante 6 meses, debido al estado de alerta como resultado de un brote de EAV (25). A pesar de este antecedente, no se evidenció la presencia de reactores al virus en estos animales importados. La ausencia de reactores en este grupo señala además, que estos animales tampoco habían sido vacunados.

Otro motivo de preocupación, lo representaba la extensa frontera con Venezuela, cercana a esta, se ubican los municipios de Arauca y Arauquita de donde procedía el $10 \%$ de las muestras; sin embargo, los resultados también fueron negativos. Surge así la necesidad de nuevos estudios en otros municipios de frontera ya que es incierta la presencia del virus en el país vecino. Un estudio preliminar en 1.008 muestras de 5 estados del centro del país, arrojó una prevalencia de $2.48 \%$ (26).

La población equina en Colombia se estima en 1.533.432 animales (27), por tanto la presencia de esta enfermedad sería devastadora para la industria nacional. En los países que han padecido los efectos de esta enfermedad, las pérdidas económicas directas se ha asociado con abortos, muerte en animales jóvenes, perdida en el valor comercial de los reproductores, disminución en la demanda de semen, gastos de vacunación, cancelación de eventos ecuestres y de mercados internacionales $(3,28)$. De allí que se requiere una vigilancia activa sobre la presencia de esta enfermedad en el país.

Se concluye que no hay evidencia de infección con EAV en la población analizada, es decir estos animales no han tenido contacto con el virus de EAV. Estos resultados son muy alentadores; sin embargo, se requieren nuevos estudios en una población más amplia, que puede hacerse extensiva a otras regiones del país para confirmar el estado de esta enfermedad exótica en Colombia.

Conflicto de intereses. Los autores declaran no tener conflicto de intereses.

\section{Agradecimientos}

Dra. Piedad Cristina Rivas Universidad de la Salle por el apoyo en la obtención de las muestras. Licenciada María Roció Parra Molina por el manejo y conservación de las muestras. 


\section{REFERENCES}

1. Balasuriya UBR, MacLachlan NJ.The immune response to equine arteritis virus:potential lessons for other arteriviruses. Vet Immunol Immunopathol 2004; 102:107-129

2. Moore $B D$, Balasuriya UBR, Nurton JP, McCollum WH, Timoney PJ, Guthrie AJ et al. Differentiation of strains of equine arteritis virus of differing virulence to horses by growth in equine endothelial cells. Am J Vet Res 2003a; 64:779-784.

3. Bell SA, Balasuriya UBR, MacLachlan J. Equine Viral Arteritis. Clin Tech Equine Pract 2006; 5:233-238

4. McFadden AM, Pearce PV, Orr D, Nicoll K, Rawdon TG, Pharo $H$, et al. Evidence for absence of equine arteritis virus in the horse population of New Zealand. N Z Vet J 2013; 61(5):300-304

5. Balasuriya UBR, Go YY, MacLachlan NJ. Equine arteritis virus. Vet Microbiol 2013; 167:93-122

6. MacLachlan NJ, Balasuriya UB. Equine viral arteritis. Adv Exp Med Biol 2006; 581:429-433

7. Guthrie AJ, Howell PG, Hedges JF, Bosman AM, Balasuriya UBR, McCollum WH et al. Lateral transmission of equine arteritis virus among Lipizzaner stallions in South Africa. Equine Vet J 2003; 35:596-600.

8. Organización Mundial de Sanidad Animal (OIE). Enfermedades, infecciones e infestaciones de la Lista de la OIE en vigor en 2013. [Fecha de acceso Octubre de 2013]. URL Disponible http:// www.oie.int/es/sanidad-animal-en-el-mundo/ enfermedades-de-la-lista-de-la-oie-2014/

9. Ruíz Sáenz J Góez Y, Urcuqui S. Góngora A, López $A$, Evidencia serológica de la infección por herpesvirus equino tipos 1 y 4 en dos regiones de Colombia, Rev Colomb Cienc Pecu 2008; 21:251-258

10. Organización Mundial de Sanidad Animal (OIE). Código Sanitario para los animales Terrestres: Infección por el virus de la arteritis equina. Volumen II, titulo 12, capítulo 12.9, 21 a edición. OIE; 2012. [Fecha de acceso Noviembre 2013]. URL Disponible http://www.oie.int/index.php?id $=169 \& \mathrm{~L}=2 \& \mathrm{htmfile}=$ chapitre $\_1.12 .9 . \mathrm{htm}$
11. Instituto Colombiano Agropecuario. Cantidad y valor de las importaciones de equinos autorizadas por el ICA e inspeccionadas por semestre y país de origen. Bogotá, Colombia; 2012. [Fecha de acceso diciembre de 2013]. ICA. URL Disponible http://www.ica.gov.co/ getattachment/cd82c461-9eb1-46d9-a5fdb90c52e17399/Importacion-Equinas-2012.aspx

12. Echeverría MG, Pecoraro MR, Galosi CM, Etcheverrigaray ME, Nosetto EO. The first isolation of equine arteritis virus in Argentina. Rev Sci Tech 2003; 22:1029-1033

13. Zhang J, Timoney PJ. Shuck KM, Seoul G, Go YY, Lu Z, et al. molecular epidemiology and genetic characterization of equine arteritis virus isolates associated with the 2006-2007 multistate disease occurrence in the USA. J Gen Virol 2010; 91:2286-2301

14. Pronost S. Pitel PH, Miszczak F, Legrand $L$, Marcillaud-Pitel C, Hamon M, et al. Description of the first recorded major occurrence of equine viral arteritis in France. Equine Vet J 2010; 42(8):713-720

15. Monreal L, Villatoro $A J$, Hooghuis $H$, Ros I, Timoney PJ. Clinical features of the 1992 outbreak of equine viral arteritis in Spain. Equine Vet J. 1995; 27(4):301-304

16. de Boer GF, Osterhaus ADME, van Oirschot JT, Wemmenhove R. Prevalence of antibodies to equine viruses in the Netherlands. Tijdschr Diergeneeskd 1979; 104:65-74

17. Vairo S, Vandekerckhove A, Steukers L, Glorieux $\mathrm{S}$, Van den Broeck W, Nauwynck H. Clinical and virological outcome of an infection with the Belgian equine arteritis virus strain 08P178. Vet Microbiol 2012; 157:333-344

18. Barrandeguy, M. EVA outbreak in Argentina. Equine Dis Quarterly 2010; 19:3-4

19. Wood JL, Chirnside ED, Mumford JA, Higgins AJ. First recorded outbreak of equine viral arteritis in the United Kingdom. Vet Rec 1995; 136:381-385. 
20. Miszczak F, Legrand L, Balasuriya UBR, FerryAbitbol B, Zhang J, Hans A, Fortier G, et al. Emergence of novel equine arteritis virus (EAV) variants during persistent infection in the stallion: Origin of the 2007 French EAV outbreak was linked to an EAV strain present in the semen of a persistently infected carrier stallion. Virology 2012; 423:165-174

21. Barbacini S. An outbreak of equine arteritis virus infection in a stallion at a Trakehner studfarm. Equine Vet Educ 2005; 17(6):294-298

22. Organización Mundial de Sanidad Animal (OIE). Informaciones sanitarias. OIE; 2012. [Fecha de acceso Noviembre de 2013] URL Disponible http://www.oie.int/wahis_2/temp/reports/ es_imm_0000012398_20121005_161133.pdf.

23. Resolución 01426. [en línea]. Bogotá, Colombia: Instituto Colombiano Agropecuario (ICA); 2002. [Fecha de acceso noviembre 2013] URL: http:// www.ica.gov.co/getattachment/413d1f7c-807942be-a643-439a209b394e/1426.aspx

24. Resolución 02820. [en línea]. Bogotá, Colombia: Instituto Colombiano Agropecuario (ICA). 2001 [Fecha de acceso Noviembre 2013] URL: http:// www.ica.gov.co/getattachment/f0d736f9-c875473e-8250-f0252dcaa7aa/2820.aspx
25. Resolución 1595. [en línea]. Bogotá, Colombia: Instituto Colombiano Agropecuario (ICA). 2010 [Fecha de acceso Noviembre 2013]. URL: http://www.icbf.gov.co/cargues/avance/docs/ resolucion_ica_1595_2010.htm.

26. Perozo E. Arteritis Viral Equina: Una Revisión. Rev Fac Cienc Vet 2005; 46(2):74-86

27. Censo equino en Colombia. [en línea]. Bogotá, Colombia: Instituto Colombiano Agropecuario (ICA). [Fecha de acceso Enero de 2014] URL: http://www.ica.gov.co/Areas/ Pecuaria/Servicios/Epidemiologia-Veterinaria/ Censos-2013.aspx

28. Holyoak GR, Balasuriya UBR, Broaddus CC, Timoney PJ. Equine viral arteritis: Current status and prevention. Theriogenology 2008; 70:403-414 